\title{
DISASTER RISK REDUCTION PENDIDIKAN KEBENCANAAN UNTUK MEMBANGUN KESADARAN, KEWASPADAAN, DAN KESIAPSIAGAAN MASYARAKAT DI KOTA SURABAYA
}

\section{DISASTER RISK REDUCTION OF EDUCATION TO BUILD COMMUNITY AWARENESS, ALERTNESS, AND PREPAREDNESS IN SURABAYA}

\author{
Ali Sahab ${ }^{1}$, Agie Nugroho Soegiono ${ }^{2}$ \\ 1,2 Fakultas Ilmu Sosial dan Ilmu Politik Universitas Airlangga \\ e-mail: ali.sahab@fisip.unair.ac.id
}

\begin{abstract}
The city of Surabaya is an area that has a high risk index for natural and non-natural disasters due to geographic and demographic conditions. The Covid-19 pandemic is a non-natural disaster that has the potential to spread massively in areas with densely populated demographic conditions such as Surabaya. Disaster education needs to be carried out to the community so that it can reduce the spread of Covid-19. This community service activity aims to provide practical knowledge to the community regarding the response to non-natural disasters of the Covid-19 pandemic. This community service activity is carried out by means of socialization and training to the community in Pacarkeling Village, Surabaya City. The results of the pre-test and post-test on people's practical knowledge showed an average increase of 70 percent. With this result, it can increase public awareness, vigilance and preparedness regarding the nonnatural disasters of the Covid-19 pandemic.
\end{abstract}

Keywords: Non-Natural Disasters, Covid-19, Disaster Education

\section{abstrak}

Kota Surabaya menjadi daerah yang memiliki indeks risiko bencana alam dan non alam yang tinggi karena kondisi geografis dan demografis. Pandemi Covid-19 merupakan bencana non alam yang sangat berpotensi menyebar secara masif pada wilayah yang memiliki kondisi demografis padat penduduk seperti Kota Surabaya. Pendidikan kebencanaan perlu untuk dilakukan kepada masyarakat sehingga dapat mengurangi penyebaran Covid-19. Kegiatan pengabdian masyarakat ini bertujuan untuk memberikan pengetahuan praktis kepada masyarakat mengenai tanggap bencana non alam pandemi Covid-19. Kegiatan pengabdian masyarakat ini dilakukan dengan cara sosialisasi dan pelatihan kepada masyarakat di Kelurahan Pacarkeling Kota Surabaya. Kegiatan dilaksanakan dalam beberapa tahap yaitu persiapan, pelaksanaan, dan evalusasi. Hasil pre-test dan post-test terhadap pengetahuan praktis masayarakat menunjukkan peningkatan rata-rata sebesar 70 persen. Dengan hasil ini dapat meningkatkan kesadaran, kewaspadaan, dan kesiapsiagaan masyarakat mengenai bencana non alam pandemi Covid-19.

Kata Kunci: Bencana Non Alam, Covid-19, Pendidikan Kebencanaan

\section{PENDAHULUAN}

Menurut The United Nations Office for Disaster Risk Reduction mengungkapkan bencana adalah kerusakan serius dari fungsi-fungsi masyarakat, yang menyebabkan kerusakan pada manusia, material dan lingkungan yang tidak bisa diatasi oleh sumber daya masyarakat sendiri (UNISDR, 2017). Wilayah Negara Kesatuan Republik Indonesia memiliki kondisi geografis dan demografis yang menjadikan sebagai daerah rawan bencana, baik yang disebabkan oleh faktor alam, faktor non alam, maupun faktor manusia yang menyebabkan timbulnya korban jiwa manusia, kerusakan lingkungan, 
kerugian secara ekonomi, dan dampak psikologis, yang dalam keadaan tertentu dapat mengganggu proses stabilitas nasional maupun internasional. Secara geografis Indonesia berada di pertemuan tiga lempeng tektonik besar, yaitu lempeng IndoAustralia, lempeng Eurasia dan lempeng Pasifik juga menyebabkan Indonesia termasuk jalur Ring of Fire atau cincin api pasifik dunia. Sedangkan secara demografis Indonesia yang berpenduduk 264 juta jiwa, sangat rawan terkena bencana kemanusia, biologis, dan pencemaran lingkungan (BPBD Jawa Timur, 2017).

Jawa Timur merupakan daerah yang memiliki indeks risiko bencana tinggi. Secara fisiografis Jawa Timur dibagi menjadi 3 bagian, yaitu zona selatan (plato), zona tengah (gunung berapi), dan zona utara (lipatan). Sedangkan secara geografis Jawa Timur memang dianggap mempunyai potensi terjadinya bencana seperti banjir, gempa bumi, puting beliung, tsunami, tanah longsor, dan sebagainya. Secara keseluruhan daerah di Jawa Timur terutama bagian selatan merupakan daerah rawan bencana alam. Sedangkan secara demografi, wilayah seperti Gerbangkertosusilo juga diangap resiko bencana non alam menjadi tinggi karena sebagai pusat demografi. Karakteristik wilayah yang urban dan padat berpotensi munculnya bencana seperti penyakit menular, pencemaran lingkungan yang tinggi dan pergesekan sosial ekonomi. Jawa Timur memiliki beberapa ancaman diantaranya bencana tsunami yang berasal dari Samudera Hindia, letusan gunung berapi aktif, serta banjir tahunan dari dua sungai besar, yaitu sungai Bengawan Solo dengan daerah yang dilaluinya seperti Kabupaten Ngawi, Tuban, Bojonegoro, Lamongan, dan Gresik dan sungai Brantas dengan daerah yang dilalui meliputi Malang, Blitar, Tulungagung, Kediri, Nganjuk, Jombang, Mojokerto, dan Surabaya.

Kota Surabaya merupakan wilayah yang berpotensi mengalami bencana alam seperti tsunami dan gempa karena dikelilingi oleh sesar kendeng dan sesar waru. Selain itu Kota Surabaya sebagai wilayah yang beresiko menghadapi berbagai bencana non alam, yaitu bencana yang diakibatkan oleh peristiwa atau rangkaian peristiwa non alam yang antara lain berupa gagal teknologi, gagal modernisasi, epidemi, dan wabah penyakit (BPBD Jawa Timur, 2017). Pandemi Covid-19 merupakan bencana non alam yang sangat berpotensi menyebar secara masif pada wilayah yang memiliki kondisi demografis padat penduduk seperti Kota Surabaya. Kota Surabaya mencatat kasus Covid-19 per Oktober 2020 sebanyak 14.817 kasus terkonfirmasi positif tepapar Covid19 dengan rate mortality sebesar 1.095 (Pemerintah Kota Surabaya, 2020).

Berdasarkan problematika tersebut bahwa perlu adanya peningkatan kapasitas serta kepekaan akan saling menjaga antar sesama dalam menghadapi pandemi Covid-19. Kondisi inilah yang menjadi fokus pengabdian masyarakat mengenai Disaster Risk Reduction (DRR) pendidikan kebencanaan untuk membangun kesadaran, kewaspadaan dan kesiapsiagaan masyarakat dalam upaya pengurangan resiko bencana Covid-19 di Kota Surabaya, lebih jauh dapat menjadi salah satu faktor penentu keberhasilan strategi pencegahan penyebaran Covid-19.

\section{METODE PENGABDIAN MASYARAKAT}

Pengabdian masyarakat ini dilaksanakan berdasarkan analisis hasil penelitian dan diskusi dengan warga masyarakat yang tinggal di Kelurahan Pacarkeling Kota Surabaya Provinsi Jawa Timur. Permasalahan yang terjadi yaitu Kota Surabaya sebagai wilayah yang rentan terhadap bencana alam dan non alam sehingga perlu meningkatkan kesadaran masyarakat mengenai antisipasi bencana. Solusi yang ditawarkan melalui 
program pengabdian masyarakat dari Lembaga Penelitian dan Pengabdian Kepada Masyarakat (LPPM) dan Fakultas Ilmu Sosial dan Ilmu Politik Universitas Airlangga yaitu pendidikan dan pelatihan kebencanaan berdasarkan Disaster Risk Reduction (DRR) meliputi sosialisasi tanggap bencana, sosialisasi gejala penyakit, dan pelatihan tanggap bencana.

Kegiatan pengabdian masyarakat ini dilaksanakan dalam beberapa tahap yaitu persiapan, pelaksanaan, dan evalusasi. Tahap persiapan dengan rincian kegiatan yaitu pembentukkan panitia pelaksana kegiatan, pembuatan proposal, melakukan proses perizinan, melakukan observasi permasalahan terhadap kondisi rawan bencana di Kelurahan Pacarkeling Surabaya (kondisi existing), membuat undangan kegiatan kepada masyarakat.

Tahap pelaksanaan dilaksanakan pada tanggal 2 November 2020 pukul 09.00-13.00 dengan rincian kegiatan yaitu melakukan sosialisasi yaitu pemahaman mengenai wabah Covid-19 serta melakukan pelatihan tanggap bencana. Metode pelaksanaannya melalui sosialisasi dan pelatihan. Monitoring dan evaluasi dikumpulkan dari data kehadiran peserta dan kemampuan masyarakat dalam mengikuti kegiatan. Observasi langsung pada saat sosialisasi dan pelatihan dengan melihat interaksi antara peserta dengan pemateri dan keaktifan masyarakat dalam acara. Evaluasi dilakukan dengan menilai peningkatan pengetahuan melalui evaluasi pre-test dan post-test terkait materi sosialisasi dan pelatihan yang dilakukan. Pelaksanaannya dilakukan dengan sosialisasi dan pelatihan, sehingga masyarakat dapat mendapatkan pengetahuan praktis yang dapat langsung diteapkan dalam kehidupan sehari-hari. Kegiatan dilakukan menggunakan metode deskriptif analitis.

Tahap evaluasi dilakukan dengan membuat laporan hasil kegiatan sosialisasi dan pelatihan yang diserahkan kepada Lembaga Penelitian dan Pengabdian Kepada Masyarakat (LPPM) Universitas Airlangga. Evaluasi dilakukan untuk mengetahui respon peserta terhadap pelaksanaan kegiatan pengabdian ini. Evaluasi dilakukan terhadap tingkat pemahaman dan partisipasi peserta kegiatan.

\section{HASIL DAN PEMBAHASAN}

Pengabdian masyarakat untuk meningkatkan kesadaran, kewaspadaan, dan kesiapsiagaan masyarakat mengenai bencana non alam telah dilakukan oleh Tim Pengabdian Masyarakat di Kelurahan Pacarkeling Kota Surabaya. Kegiatan diikuti oleh masyarakat setempat yang terdiri dari kelompok PKK, karang taruna, dan masyarakat. Kegiatan ini dilakukan pada tanggal 2 November 2020 berupa sosialisasi dari pihak akademisi dan pelatihan dari pihak praktisi.

Kegiatan sosialisasi dilakukan oleh pihak akademisi yang mempuni di bidangnya mengenai bencana non alam yaitu virus Covid-19. Kegiatan sosialisasi dilakukan dengan menggunakan metode pemaparan secara visualisasi melalui aplikasi Zoom Meeting. Sebelum melakukan sosialisasi, dilakukan pre-test terlebih dahulu untuk mengetahui sampai mana pemahaman masyarakat di Kelurahan Pacarkeling Kota Surabaya. Sosalisasi ini dilakukan untuk mengatasi permasalahan pada masyarakat setempat yaitu perlu untuk meningkatkan kesadaran, kewaspadaan, dan kesiapsiagaan masyarakat dalam menjalani kehidupan selama pandemi Covid-19. 
Kegiatan pelatihan dilakukan oleh pihak praktisi yang berasal dari Badan Penanggulangan Bencana dan Perlindungan Masyarakat Kota Surabaya mengenai tanggap bencana non alam. Kegiatan pelatihan dilakukan dengan metode pemberian materi pelatihan mengenai tanggap bencana non alam. Kegiatan pelatihan bertujuan untuk membentuk cara dan sikap yang tepat masyarakat apabila terkena Covid-19 atau apabila orang terdekat terkena Covid-19.

Respon peserta terhadap pelaksanaan kegiatan pengabdian masyarakat ini ditujukkan dengan dilakukan evaluasi sebelum dan sesudah pelaksanaan kegiatan. Evaluasi dimaksudkan untuk mengetahui peningkatan pemahaman dan partisipasi peserta. Hal ini dilakukan melalui pre-test dan post-test terhadap masyarakat di Kelurahan Pacarkeling Kota Surabaya untuk mengetahui tingkat pemahaman dan partisipasi dalam kegiatan terkait kesadaran, kewaspadaan, dan kesiapsiagaan masyarakat dalam menghadapi pandemi Covid-19.

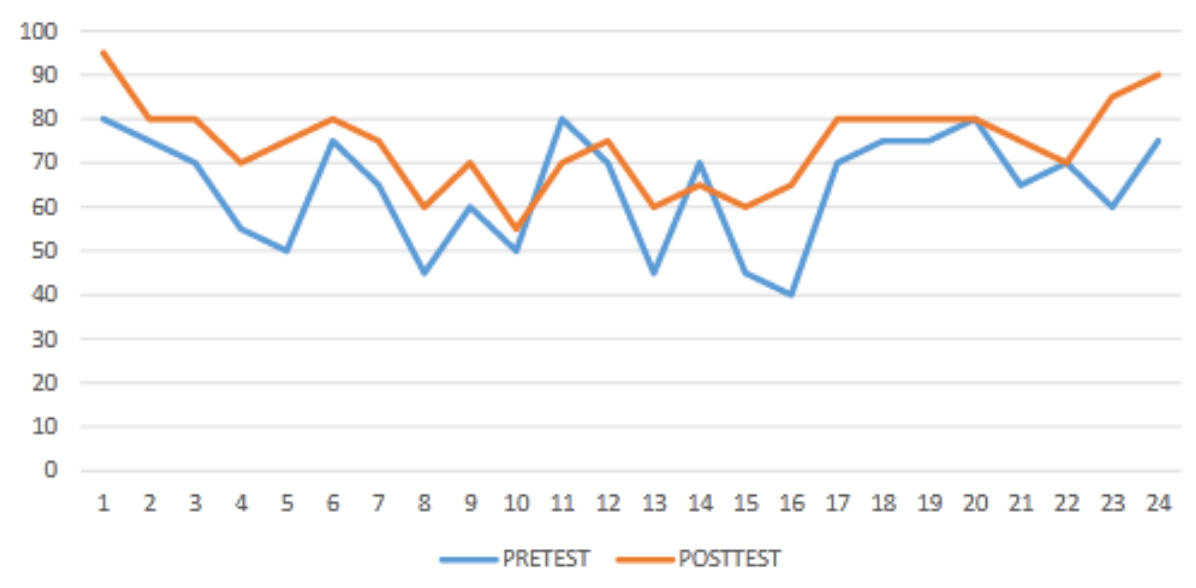

\section{Tabel 1. Distribusi Peningkatan Pemahaman Masyarakat Peserta Pengabdian Masyarakat Sebelum dan Sesudah Kegiatan}

Berdasarkan hasil evaluasi pres-test dan post-test yang telah dilakukan sebelum dan sesudah pelaksanaan sosialisasi dan pelatihan kegiatan pengabdian masyarakat mendapati bahwa perserta yang terdiri dari kelompok PKK, karang taruna, dan masyarakat di Kelurahan Pacarkeling Kota Surabaya mengalami peningkatan pemahaman mengenai tanggap bencana non alam pandemi Covid-19. Pemberian sosialisasi dan pelatihan dapat meningkatkan kapasitas peserta sehingga masyarakat mampu memahami dan menyerap serta memiliki pengetahuan terkait kesadaran, kewaspadaan, dan kesiapsiagaan masyarakat dalam menghadapi pandemi Covid-19. Hal ini dibuktikan dengan hasil nilai pre-test (sebelum kegiatan) lebih tinggi dibandingkan nilai post-test (sesudah kegiatan). Dari 25 orang peserta, hanya 3 orang saja yang memiliki nilai pre-test dan post-test yang hampir sama, selebihnya terjadi peningkatan yang sangat signifikan. Sedangkan rata-rata peningkatan pemahaman sebesar 70 persen. Hal ini mengindikasikan bahwa hasil dari kegiatan pengabdian masyarakat tentang sosialisasi dan pelatihan mengenai tanggap bencana non alam pandemi Covid-19 dapat dikatakan berhasil. 


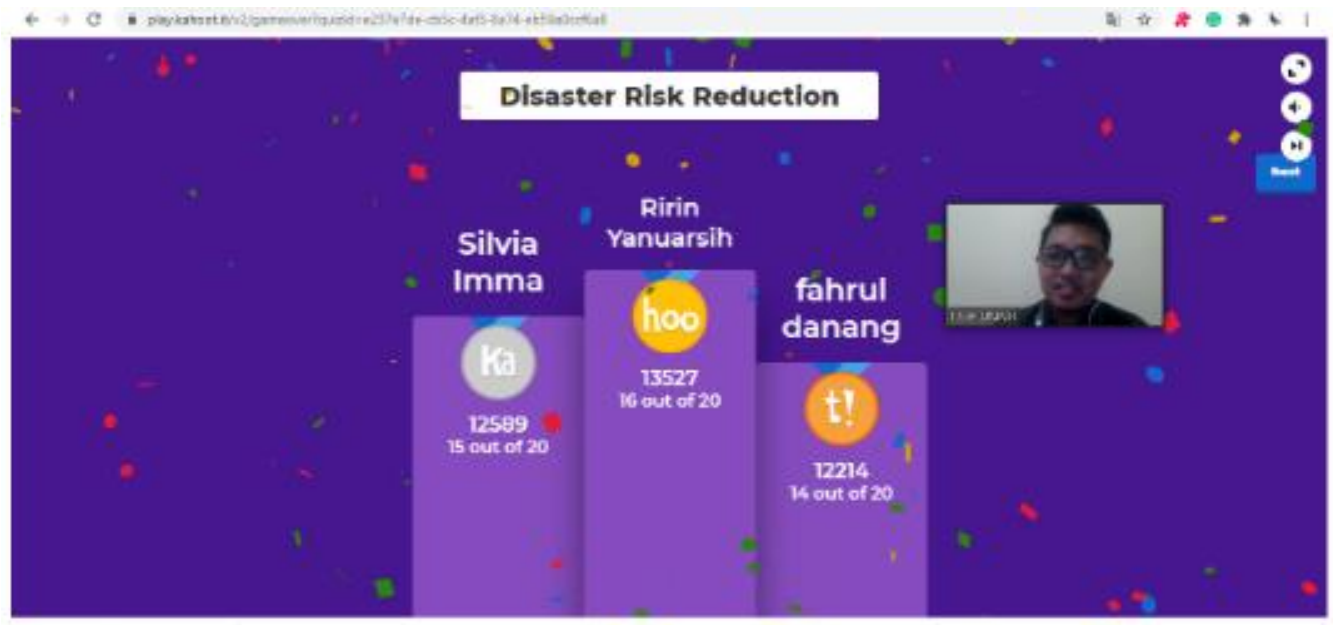

Gambar 1. Sosialisasi Mengenai Disaster Risk Reduction

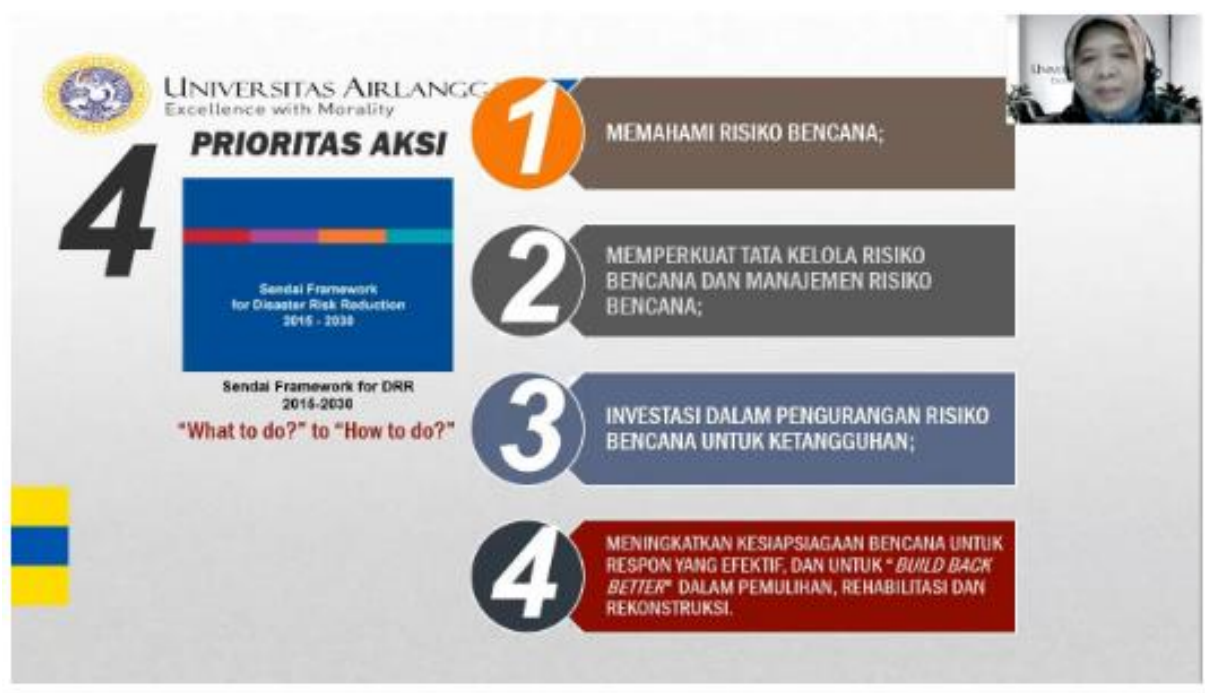

Gambar 2. Sosialisasi Mengenai Tanggap Bencana Non Alam Pandemi Covid-19

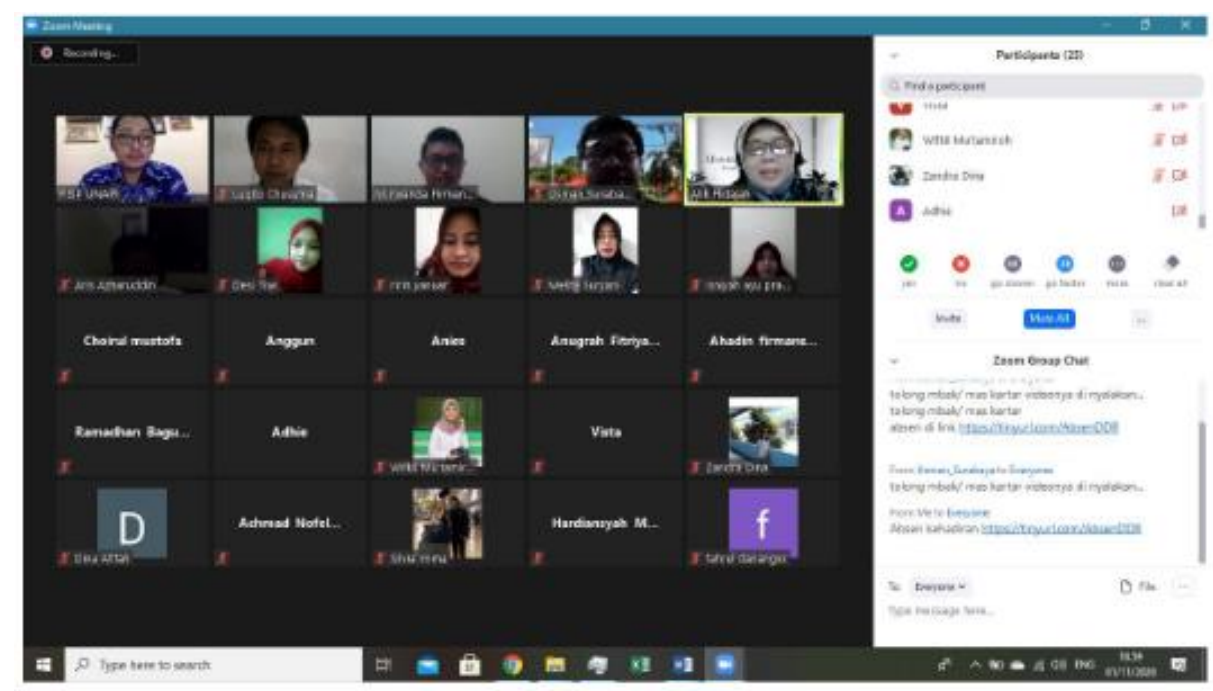

Gambar 3. Peserta Kegiatan Pengabdian Masyarakat 
Pelaksanaan kegiatan pengabdian masyarakat di Kelurahan Pacarkeling Kota Surabaya ini berjalan dengan baik dan lancar. Pengabdian ini ditujukan kepada berbagai lapisan masyarakat yang ada dengan menggunakan metode sosalisasi yaitu pemaparan materi yang dilakukan oleh para narasumber dan pelatihan yang dilakukan oleh praktisi. Pengabdian masyarakat ini mampu menambah pemahaman masyarakat mengenai bencana non alam pandemi Covid-19 sehingga dapat meningkatkan kesadaran, kewaspadaan, dan kesiapsiagaan masyarakat.

Dalam proses kegiatan berjalan seperti yang diharapkan yang dibuktikan dengan respon para peserta dalam menjawab pertanyaan yang diajukan dengan baik dan benar. Masyarakat juga memperhatikan proses sosialisasi maupun pelatihan yang dilakukan pada kegiatan ini berjalan dengan baik.

Berdasarkan hasil evaluasi pelaksanaan kegiatan terdapat faktor pendukung dan penghambat dari kegiatan ini sehingga dapat berjalan dengan baik dan lancar. Faktor pendukung yaitu adanya dukungan dari berbagai pihak dari pihak kelurahan, ketua RT, dan berbagai kelompok lapisan masyarakat serta mitra yang terkait. Sedangkan faktor penghambat yaitu kegiatan ini dilaksanakan dalam kondisi Pandemi Covid-19 sehingga harus dilaksanakan secara virtual.

\section{PENUTUP}

\section{Simpulan}

Kegiatan pengabdian masyarakat ini memberikan pengetahuan praktis kepada masyarakat dengan cara sosialisasi dan pelatihan di Kelurahan Pacarkeling Kota Surabaya mengenai pentingnya manajemen bencana non alam pandemi Covid-19 di Kota Surabaya. Dengan pelaksanaan kegiatan pengabdian masyarakat ini memberikan peningkatan pengetahuan terhadap masyarakat, ditunjukkan dengan peningkatan signifikan nilai pre-test dan post-test serta respon peserta dalam kegiatan. Dengan hasil ini dapat meningkatkan kesadaran, kewaspadaan, dan kesiapsiagaan masyarakat mengenai bencana non alam pandemi Covid-19.

\section{Saran}

Kegiatan pengabdian masyarakat ini perlu dilakukan secara berkesinambungan dan perlu untuk dikembangkan lebih lanjut dalam melihat keefetivitasan kegiatan dalam menangani permasalahan yang sedang terjadi. Peran aktif berbagai pihak perlu diwujudkan dalam bentuk kegiatan untuk membentuk persepsi masyakat dalam merespon pandemi Covid-19 kedepannya. Terakhir, pelaksanaan pelatihan tanggap bencana perlu dilakukan secara terus menerus mengingat antusiasme masyarakat desa tentang pola hidup sehat sangat tinggi.

\section{Ucapan Terima Kasih}

Tim pengabdian masyarakat mengucapkan terima kasih atas bantuan pendanaan dari Keputusan Rektor Universitas Airlangga Nomor 523/UN3/2020 tanggal 1 Juli 2020 Tentang Pelaksanaan Program Pengabdian Kepada Masyarakat Universitas Airlangga Tahun 2020. Tim pengabdian masyarakat juga mengucapkan terima kasih kepada institusi mitra Badan Penanggulangan Bencana dan Perlindungan Masyarakat Kota Surabaya dan Pemerintah Kelurahan Pacakeling Kota Surabaya yang telibat dalam kegiatan pengabdian ini. 


\section{DAFTAR PUSTAKA}

BPBD Jawa Timur. 2017. Definisi dan Jenis Bencana. BPBD. https://web.bpbd.jatimprov.go.id/2017/06/01/definisi-dan-jenis-bencana/

Pemerintah Kota Surabaya. 2020. Surabaya Lawan Covid-19. https://lawancovid19.surabaya.go.id/, 5 Oktober 